"Obsiah realizovanykh posluh za vydamy ekonomichnoi diialnosti po Kharkivskii oblasti" [Volume of Sold Services by Types of Economic Activity in Kharkiv Region]. Holovne upravlinnia statystyky u Kharkivskii oblasti. http://kh.ukrstat.gov.ua/informatsiine-suspilstvostat/3379-obsyag-realizovanikh-poslug-za-vidamiekonomichnoji-diyalnosti-po-kharkivskij-oblasti

Poltorak, K. A., and Zozulyov, O. V. "Zastosuvannia kraudtekhnolohii v marketynhovii diialnosti pidpryiemstv" [Use of Crowd-Technologies in Marketing Activities of Enterprises]. Ekonomichnyi visnyk Natsionalnoho tekhnichnoho universytetu Ukrainy «Kyivskyi politekhnichnyi instytut». 2014. https://ela.kpi.ua/bitstream/123456789/11872/1/66.pdf

"Reiestr krashchykh postachalnykiv tovariv ta posluh $2019^{\prime \prime}$ [Register of the Best Suppliers of Goods and
Services 2019]. Vseukrainskyi haluzevo-analitychnyi tsentr. https://ukr-centr.com.ua/rate_2019_vs_ nat?edrpou $=35417654$

Tovt, T. I., and Drozd, N. V. "Napriamky zastosuvannia kraud-tekhnolohii u diialnosti pidpryiemstv" [Directions of Application of Crowd-Technologies in the Activities of Enterprises]. Naukovyi visnyk Mukachivskoho derzhavnoho universytetu. Seriia «Ekonomika», no. 2 (2019): 80-85.

DOI:10.31339/2313-8114-2019-2(12)-80-85

Zavydivska, O. I. "Kraudsorsynh yak innovatsiinyi instrument zabezpechennia rozvytku personalu" [Crowdsourcing as an Innovative Tool for Staff Development]. Suchasni tekhnolohii menedzhmentu, informatsiine, finansove ta oblikove zabezpechennia rozvytku ekonomiky $\mathrm{v}$ umovakh yevrointehratsii. 2020. http://www.suem.edu. ua/documents/tezy_conference_2020_04.pdf

\title{
MODELING ACCOUNTING POLICIES FOR THE HOSPITALITY INDUSTRY IN THE CONTEXT OF GLOBALIZATION
}

\author{
${ }^{\odot 2020}$ NESTERENKO I. V., KOVALEVSKA N. S., SOKOLOVA E. B.
}

UDC 657.2:005.44:640.4

JEL: M41; M49

\section{Nesterenko I. V., Kovalevska N. S., Sokolova E. B. Modeling Accounting Policies for the Hospitality Industry in the Context of Globalization}

The article is aimed at substantiating the organizational and methodical provisions, elaborating practical recommendations to improve the accounting policy of the hospitality industry enterprises. An optimization model of the accounting policy of hotel enterprises is proposed, allowing to identify the accounting-analytical resources of management in terms of the allocated reporting economic segments and on their basis to form reporting by the hotel segments. Developing the theory of costs classification, it is determined that the grouping of costs be appropriate to carry out by the most significant hotel segments, which meets the tasks of costs management, based on the characteristics of the hotel activity, creates conditions for economic substantiation of the goals of the structural units. Expediency of the maximum integration of the hotel's accounting policy in accordance with international standards and national regulations that define the specifics of its formation is proved. In order to improve the costs management process of the hotel industry enterprises by segment, a sub-accounts system to the account 23 "Production» is recommended, wherein the second-order sub-accounts match the basic, supportive and additional level of services, and the third-order accounts match the enterprise's production services. The proposed accounting policy model allows for rationalizing the process of formation of information resources at different levels of the hotel enterprise management and developing methodical principles for reflecting hotel services in accounting in accordance with the requirements of both international and national financial reporting standards.

Keywords: accounting policy, hotel, accounting, modeling, costs.

DOI: https://doi.org/10.32983/2222-4459-2020-6-212-218

Fig.: 4. Tabl.: 1. Bibl.: 10.

Nesterenko Irina V. - PhD (Economics), Associate Professor of the Department of Finance and Accounting, Kharkiv State University of Food Technology and Trade (333 Klochkivska Str., Kharkiv, 61051, Ukraine)

E-mail: irina_nest@bigmir.net

Kovalevska Nadiia S. - PhD (Economics), Associate Professor ma epy Department of Commodity Science, Trade and Product Quality Management, Kharkiv State University of Food Technology and Trade (333 Klochkivska Str., Kharkiv, 61051, Ukraine)

E-mail: kavalserg@gmail.com

Sokolova Evgenia B. - PhD (Engineering), Senior Lecturer of the Department of Commodity Science, Trade and Product Quality Management, Kharkiv State University of Food Technology and Trade (333 Klochkivska Str., Kharkiv, 61051, Ukraine)

E-mail: evgenia-sokolova@ukr.net

ORCID: http://orcid.org/0000-0002-6246-6012

УДК 657.2:005.44:640.4

JEL: M41; M49

Нестеренко І. В., Ковалевська Н. С., Соколова Є. Б. Моделювання облікової політики підприємств готельної індустрії в умовах глобалізації Метою статті є обгрунтування організаційних і методичних положень, розробка практичних рекомендацій з удосконалення облікової політики підприємств готельної індустрії. Запропоновано оптимізаційну модель облікової політики готельних підприємств, яка дозволяє отримувати обліково-аналітичні ресурси управління в розрізі виділених звітних господарських сегментів та на їх основі складати звітність за сегментами готелю. Розвиваючи теорію класифікації витрат, визначено, що групування витрат доцільно здійснювати за найбільш впливовими сегментами готелю, що відповідає завданням управління витратами, виходячи із особливостей готельної діяльності, створює умови економічного обгрунтування цілей структурних підрозділів. Доведено доцільність максимальної інтеграції облікової політики готелю за міжнародними стандар- 
тами та національними нормативними документами, які визначають особливості їі формування. 3 метою вдосконалення процесу управління витратами підприємств готельної індустрії за сегментами рекомендовано систему субрахунків до рахунка 23 «Виробництво», в якій субрахунки другого порядку відповідають основному, допоміжному та додатковому рівню послуг, а рахунки третього порядку - виробничим службам підприємства. Застосування запропонованої методики обліку витрат готельного підприємства дозволить встановити контроль над рівнем фактичних витрат, їх нормативними та плановими показниками, а також сприятиме калькулюванню собівартості готельних послуг. Запропонована модель облікової політики дозволяє раціоналізувати процес формування інформаційних ресурсів на різних рівнях управління готельним підприємством і розробити методичні засади відображення готельних послуг у бухгалтерському обліку відповідно до вимог міжнародних і національних стандартів фінансової звітності.

Ключові слова: облікова політика, готель, облік, моделювання, витрати.

Рис.: 4. Табл.: 1. Бібл.: 10

Нестеренко Ірина Володимирівна - кандидат економічних наук, доцент кафедри фінансів та обліку, Харківський державний університет харчування та торгівлі (вул. Клочківська, 333, Харків, 61051, Україна)

E-mail: irina_nest@bigmir.net

Ковалевська Надія Сергіївна - кандидат економічних наук, доцент кафедри товарознавства, торгівлі та управління якістю товарів, Харківський державний університет харчування та торгівлі (вул. Клочківська, 333, Харків, 61051, Україна)

E-mail: kavalserg@gmail.com

Соколова Євгенія Борисівна - кандидат технічних наук, старший викладач кафедри товарознавства, торгівлі та управління якістю товарів, Харківський державний університет харчування та торгівлі (вул. Клочківська, 333, Харків, 61051, Україна)

E-mail: evgenia-sokolova@ukr.net

ORCID: http://orcid.org/0000-0002-6246-6012

УДК 657.2:005.44:640.4

JEL: M41; M49

Нестеренко И. В., Ковалевская Н. С., Соколова Е. Б. Моделирование учетной политики предприятий гостиничной индустрии в условиях глобализации

Целью статьи является обоснование организационных и методических положений, разработка практических рекомендаций по усовершенствованию учетной политики предприятий гостиничной индустрии. Предложена оптимизационная модель учетной политики гостиничных предприятий, которая позволяет выявить учетно-аналитические ресурсы управления в разрезе выделенных отчетных хозяйственных сегментов и на их основе формировать отчетность по сегментам гостиницы. Развивая теорию классификации расходов, определено, что группирование расходов целесообразно осуществлять по наиболее весомым сегментам гостиницы, что отвечает задачам управления расходами, исходя из особенностей гостиничной деятельности, создает условия экономического обоснования целей структурных подразделений. Доказана целесообразность максимальной интеграции учетной политики гостиницы в соответствии с международными стандартами и национальными нормативными документами, которые определяют особенности её формирования. С целью усовершенствования процесса управления расходами предприятий гостиничной индустрии по сегментам рекомендована система субсчетов к счету 23 «Производство», в которой субсчета второго порядка отвечают основному, вспомогательному и дополнительному уровню услуг, а счета третьего порядка - производственным службам предприятия. Предложенная модель учетной политики позволяет рационализировать процесс формирования информационных ресурсов на разных уровнях управления гостиничным предприятием и разработать методические принципы отражения гостиничных услуг в бухгалтерском учете в соответствии с требованиями международных и национальных стандартов финансовой отчетности.

Ключевые слова: учетная политика, гостинииа, учет, моделирование, расходы.

Рис.: 4. Табл.: 1. Библ.: 10.

Нестеренко Ирина Владимировна - кандидат экономических наук, доцент кафедры финансов и учета, Харьковский государственный университет питания и торговли (ул. Клочковская, 333, Харьков, 61051, Украина)

E-mail: irina_nest@bigmir.net

Ковалевская Надежда Сергеевна - кандидат экономических наук, доцент кафедры товароведения, торговли и управления качеством товаров, Харьковский государственный университет питания и торговли (ул. Клочковская, 333, Харьков, 61051, Украина)

E-mail: kavalserg@gmail.com

Соколова Евгения Борисовна - кандидат технических наук, старший преподаватель кафедры товароведения, торговли и управления качеством товаров, Харьковский государственный университет питания и торговли (ул. Клочковская, 333, Харьков, 61051, Украина)

E-mail: evgenia-sokolova@ukr.net

ORCID: http://orcid.org/0000-0002-6246-6012

$\mathrm{T}$ he growth in the share of the hospitality and tourism industry in the world economy, formation of the global hotel chain and associations, diversification of the hotel business are the main trends in the international hospitality industry in the context of globalization. In the process of synergetic management, due to the development of tourism and intensification of business mobility, there observed: a growing volume of hotel services; increasing requirements for quality and range of services in the hospitality industry. All the trends are primarily associated with changes in the duration of holidays, diversity of recreational tourist services, increasing requirements for quality of hotel services as well as growing number of foreign tourists, Ukraine's participation in the world economic, scientific, educational and cultural space.

Given the relevance of the topic, especially in the context of globalization of the hospitality industry, many authors (Yu. Veryha, O. Vysochan, H. Davydov, M. Korinko, A. Mazaraki, Yu. Manachynska, M. Pushkar, L. Yanchevata, and others) in their works highlight organizational and methodological aspects of accounting and internal auditing of services provided by various sec- 
tors of the economy, including the hospitality industry. Some theoretical and applied aspects of the operation of the hospitality industry are studied in the papers of L. Lukianova, O. Melnyk, I. Minich, S. Skobkin, L. Shmatko, and others. Taking into consideration all the mentioned results, it should be noted that the theoretical and methodological issues of hotel accounting are limited to fragmentary studies of the display of settlement transactions; evaluation of profitability; cost of services; assessment of investment policy effectiveness. The issues of forming accounting policies for the hospitality industry remain insufficiently developed.

The aim of the article is to substantiate theoretical and methodological principles and develop practical recommendations aimed to improve information tools for modelling accounting policies for the hospitality industry in the context of globalization.

$\mathrm{T}$ he growth in the investment attractiveness of the sector of hotel services requires re-equipment and significant capital investments in the hospitality industry. At the same time, inefficient resource management hinders optimizing activities of hotels, improving the quality of services, increasing profitability, which requires implementing effective accounting policies. A balanced and effective model of accounting policies would contribute to enhancing efficiency of a hotel.

Therefore, it is advisable to start the development of accounting policies for hotels with analyzing information needs of hotel management and its current problems, in particular: inefficient use of the existing tools to influence consumers (insufficient use or misuse of the whole complex of marketing, organizational and financial tools, as well as related resources for making informed decisions by consumers); lack of information on the formation of hotel complex centers, distribution of operational and managerial functions and responsibilities among them, their interaction with the administration of the hotels; inconsistency between the organizational structure and the strategy, goals and objectives of development of the hotel; inefficiency of functional interconnections between business units of the hotel; lack of a mechanism for implementing timely adjustments in the organizational structure of the hotel; lack of a systems and interconnected customer-oriented management approach based on correct distribution of management priorities and adequate allocation of the hotel's resources among its units.

The expediency of developing enterprise accounting policy is established by law. In particular, the Law of Ukraine "On Accounting and Financial Reporting in Ukraine" (Art. 1) defines it as "a set of principles, methods, and procedures applied by an enterprise to prepare and present its financial statements". Art. 5 of the Law states that "... an enterprise chooses its accounting policy independently ..." [1]. The IAS 8 "Accounting Policies, Changes in Accounting Estimates and Errors" defines the concept under study as "the specific principles, bases, conventions, rules and practices applied by an entity in preparing and presenting financial statements" [5]. In contrast to Ukrainian regulations $[1 ; 2]$, IAS 8 , to denote the concept, uses the plural form. This is due to the fact that according to the international rules, the accounting policy that is established in respect of a particular object of accounting is considered a separate accounting policy. Based on the national definition, the set of such accounting policies constitutes a single accounting policy of an enterprise.

Professor M. S. Pushkar, believes that "accounting policy is a regulation (collection of rules) under which Accounting Department carries out financial and management accounting ..." [4].

The analysis of the interpretations of the concept "accounting policy" indicates that there is high scientific and practical interest in the studied category and the lack of a unified and unambiguous approach due to multifaceted nature of the concept. Scientific sources and accounting regulations contain a wide range of opinions on how to interpret "accounting policy". Thus, ambiguous approaches to accounting policy interpretation, the ignorance of its importance for the rationalization of hotel management are due to the lack of standards in Ukraine that would provide for clear parameters of hotel accounting policy, its justification, formation and variability. Modeling accounting policies depends on accommodation specifics, which should be classified by form (hotel and non-hotel facilities) and type (collective and individual accommodation facilities) (Fig. 1).

$\mathrm{A}$ large number of goals and objectives of the hotel accounting policy implies the presence of a wide range of economic interests when choosing a particular accounting option. The management of a hotel, when defining the elements of its accounting policy, should set several interrelated goals, which it seeks to achieve through effectively constructed accounting policy.

The studied scientific publications and relevant regulations define the following accounting policy goals: reporting (42\% of the literature sources) $[1 ; 5 ; 7 ; 9, \mathrm{p}$. 25 ; 10 , p. 155]; keeping records (38\% of the literature sources) [10], organizing accounting (19\% of the literature sources) [10], accounting management (9.5\% of the literature sources) [5]; creating the hotel management system (9.5\% of the literature sources) [7] and forming information resources for managers $(4.8 \%$ of the studied literature sources) [4]. With consideration for the results of the analysis of approaches to defining accounting policy, we propose to interpret it as a hotel's choosing specific methods, techniques, forms for organizing, managing accounting and financial reporting, based on the established rules and features of its activities (organizational and technological characteristics, the number and qualifications of accounting staff, the level of technological equipment of Accounting Department, the number of units, etc.) [6]. 


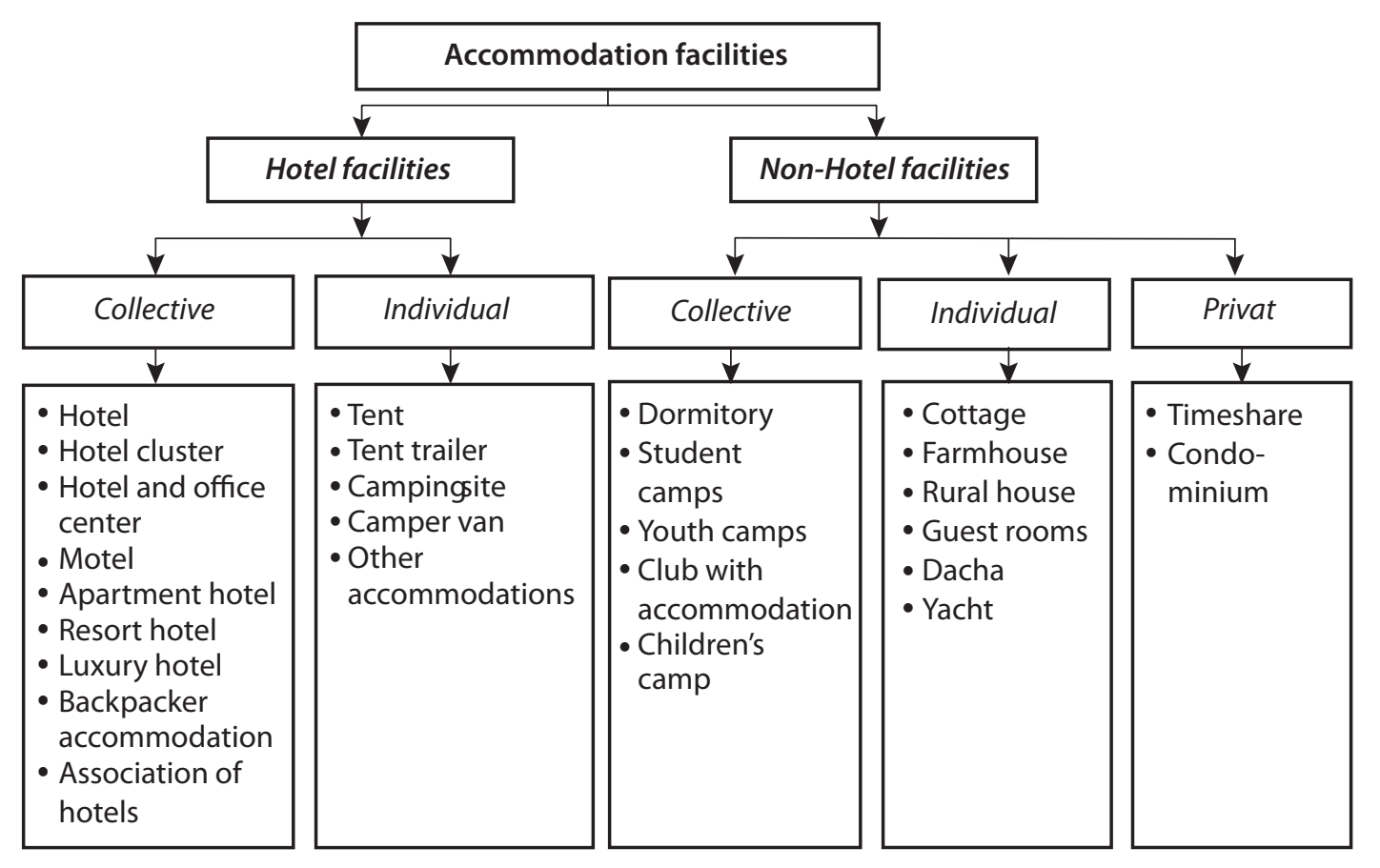

Fig. 1. Classification of different types of accommodation facilities

According to I. Pryanichnikova, the document on accounting policy, drawn up in accordance with the requirements of IFRS, can consist of three sections and appendices: general provisions, organizational section, methodological section [3]. However, most scientists studying the theoretical and practical parts of accounting policy, propose to single out such sections as general provisions, methodology, technical issues and organization of accounting [8]. In our opinion, these sections include all the necessary aspects of building an accounting information system for hotels and should be clearly defined in the Order on the accounting policy. In terms of organizational, technical, methodological sections of the Order on the accounting policy for hotels, we propose to single out the elements shown in Fig. 2, which will create a model of the optimal accounting policy of a hotel.

I $\mathrm{n}$ order to meet the needs of hotel management, special attention should be paid to operating costs and classifying them according to accounting items. At the same time, the grouping should be made by expense centers, expense sources, responsibility centers. The singling out of the second group is conditioned by the need for calculations, and the items of this group are sources of expenses, which might be considered as types of hotel services. In order to increase efficiency of accounting in hotels it is recommended to introduce a hierarchical system for classifying a hotel's expenses (Fig. 3).

The advantages of this classification system are: a practical approach for expenses classification, consideration for peculiar features of a hotel's activities, which complies with the tasks of cost management; accuracy in assessment of the hotel's KPIs and credibility of the information presented in financial and internal reporting. The process of modeling accounting policies should include studying the specifics of the hospitality industry and developing elements relevant to the features of the process of providing hotel services (Tbl. 1).

$\mathrm{D}$ epending on the specifics of the hotel, the volume of its activity, the number of suppliers and contractors, in terms of basic and additional services, at the next stage of accounting policies modeling, it is advisable to develop a current chart of accounts. In order to optimize activities of hotels, we recommend opening sub-accounts in addition to those of the standard chart of accounts, which will increase the transparency of accounting procedures, promote rational organization of accounting management at the hotel (Fig. 4).

An important role in determining the organizational accounting issues in a hotel is played by telecommunication systems and information technologies both in recordkeeping and management of the hotel. The latest integrated hotel automation systems help increase efficiency of accounting (accounting of cash flows, cost of services provided, income received, etc.) based on the information on room reservation, hotel occupancy, guest accommodation, room availability, scheduled check-ins and checkouts, provision of food, and other related services.

We propose to improve the methodological section of the hotel accounting policy, and for this purpose, it is necessary to:

+ separately disclose the features of income recognition of other selected segments (except for the method of recognizing income from hotel services);

+ determine the method of transfer pricing and the method of distribution of overhead costs of the hotel; 


\begin{tabular}{|c|c|c|c|}
\hline \multirow[b]{2}{*}{$\nabla$} & \multicolumn{2}{|c|}{ Order on the accounting policy of a hotel } & \multirow[b]{2}{*}{$\nabla$} \\
\hline & $\nabla$ & $\downarrow$ & \\
\hline $\begin{array}{c}\text { Elements } \\
\text { of General } \\
\text { provisions section }\end{array}$ & $\begin{array}{l}\text { Elements } \\
\text { of Organizational } \\
\text { section }\end{array}$ & $\begin{array}{l}\text { Elements } \\
\text { of Technical } \\
\text { section }\end{array}$ & $\begin{array}{c}\text { Elements } \\
\text { of Methodological } \\
\text { section }\end{array}$ \\
\hline$\downarrow$ & $\nabla$ & $\downarrow$ & $\downarrow$ \\
\hline $\begin{array}{l}\text { - Name of the hotel } \\
\text { - Location } \\
\text { of the hotel } \\
\text { - Form of ownership } \\
\text { - Legal form } \\
\text { - Presence } \\
\text { of branches } \\
\text { and other structural } \\
\text { subdivisions } \\
\text { assigned } \\
\text { to a separate } \\
\text { balance sheet } \\
\text { - Presence } \\
\text { of business } \\
\text { segments } \\
\text { - Activities } \\
\text { in accordance } \\
\text { with the charter } \\
\text { documents } \\
\text { of the hotel }\end{array}$ & $\begin{array}{l}\text { - Organization } \\
\text { of accounting work } \\
\text { - The structure } \\
\text { of the accounting } \\
\text { and analytical service } \\
\text { - The level } \\
\text { of centralization } \\
\text { of accounting work } \\
\text { - Options to organize } \\
\text { management } \\
\text { accounting service } \\
\text { - List of responsibility } \\
\text { centers } \\
\text { - List of cost centers } \\
\text { - Information } \\
\text { constituting trade } \\
\text { secret the procedure } \\
\text { for its protection }\end{array}$ & $\begin{array}{l}\text { - Current chart of accounts } \\
\text { - Form of accounting } \\
\text { - Technologies used } \\
\text { for processing accounting } \\
\text { information } \\
\text { - System of accounting } \\
\text { registers, forms } \\
\text { of primary documents, } \\
\text { schedule of document } \\
\text { circulation } \\
\text { - Reporting structure } \\
\text { and procedure } \\
\text { - Procedure for taking } \\
\text { inventory of assets } \\
\text { and liabilities } \\
\text { - List of the software, } \\
\text { devices, etc. } \\
\text { - Procedure for ensuring } \\
\text { the storage } \\
\text { and confidentiality } \\
\text { of information }\end{array}$ & $\begin{array}{l}\text { - Method of accounting } \\
\text { valuation (revaluation) } \\
\text { - Methods of inventory } \\
\text { disposal valuation } \\
\text { - Methods and procedure } \\
\text { for asset depreciation } \\
\text { - Procedure for writing off } \\
\text { the inventory value } \\
\text { - Determination of the } \\
\text { structure of deferred } \\
\text { expenses and the } \\
\text { procedure for their } \\
\text { writing off } \\
\text { - Procedure for creating } \\
\text { reserves } \\
\text { - Mechanism for calculating } \\
\text { the cost of hotel services } \\
\text { - Procedure for recognizing } \\
\text { income from the provision } \\
\text { of hotel services } \\
\text { - Procedure for deferred } \\
\text { income accounting } \\
\text { - Distribution of tangible } \\
\text { assets to fixed assets and } \\
\text { non-current tangible assets } \\
\text { - Determination of the } \\
\text { significance of the data } \\
\text { to be disclosed } \\
\text { in the report }\end{array}$ \\
\hline
\end{tabular}

Fig. 2. Model of the Order on the accounting policy of a hotel

+ unify the methods of depreciation of non-current assets of hotels by units;

+ valuate inventory disposal in the segment of hotel services using the FIFO method, and in the restaurant segment (due to the short shelf life of the stock) - by the weighted average cost method;

+ enshrine in legislation use the method of writing off the work uniform cost for the restaurant segment and to establish the cost criterion for capitalization of the cost of the uniform for the hotel segment;

+ organize analytical cost accounting in accordance with the needs of calculating the cost of hotel services, with consideration for the specifics and technology of their provision [6].

\section{CONCLUSIONS}

Thus, the results of the scientific research proved the feasibility of maximum integration of Ukraine into common economic space. For this purposes, it is necessary to achieve the compliance of accounting policies with international standards and national regulations, which determine the specific of its formation. To optimize the accounting process in the hospitality industry, it is recommended to implement the proposed model, which allows obtaining accounting and analytical management resources with consideration for the specific features of hotel facilities.

It can provide a basis for financial reporting, which will improve hotel management efficiency with neither considerable changes in the organizational structure nor significant financial investments.

\section{LITERATURE}

1. Закон України «Про бухгалтерський облік та фінансову звітність» від 16.07.1999. № 996. URL: https:// zakon.rada.gov.ua/laws/show/996-14 


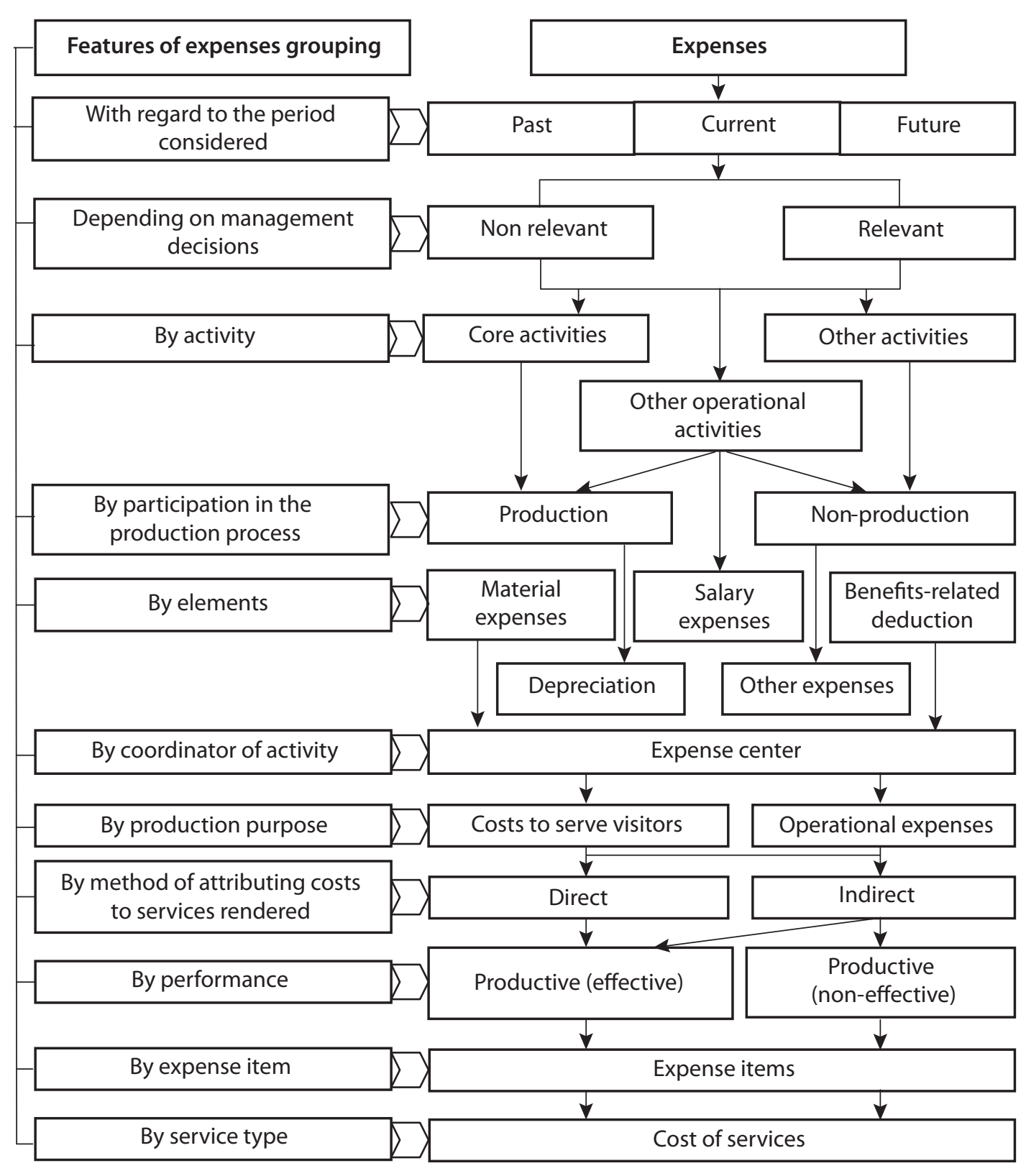

Fig. 3. Hierarchical system of classification of hotel expenses

2. Лист Міністерства фінансів України «Про облікову політику» від 21.12.2005 р. № 31-34000-10-5/27793. URL: http://195.78.68.18/minfin/control/uk/publish/ article?art_id=58984\&cat_id=34931

3. Пряничникова И. Первый шаг к МСФО: новая учетная политика. Баланс. 2007. № 63. С. 31-34.

4. Пушкар М. С. Облікова політика і звітність : навч. посіб. Тернопіль : Карт-бланш, 2004. 141 с.

5. МСБО (IAS) 8. Облікові політики, зміни в облікових оцінках та помилки. URL: https://zakon.rada.gov.ua/ laws/show/929_020

6. Янчева Л. М., Герасимова Н. С., Левіна М. В. Облік і аудит готельних послуг : монографія. Харків :ХДУХТ, 2013. $208 \mathrm{c}$.

7. Ілляшенко К. В. Інформаційний аспект облікової політики. URL: http://конференция.com.ua/pages/ view/307

8. Щирба М. Проблеми документального оформлення облікової політики підприємства та шляхи їх вирішення. Економічний аналіз. 2010. Вип. 5. С. 380-384.
9. Кучеренко Т. Регламентування облікової політики фінансової звітності. Бухгалтерський облік і аудит. 2009. № 5. С. 24-34.

10. Лебедзевич Я. В. Вплив облікової політики підприємства на доходи і результати діяльності. Вісник ЖITI. 2001. № 15. C. 155-162.

\section{REFERENCES}

Illiashenko, K. V. "Informatsiinyi aspekt oblikovoi polityky" [Information Aspect of Accounting Policy]. http:// конференция.com.ua/pages/view/307

Kucherenko, T. "Rehlamentuvannia oblikovoi polityky finansovoi zvitnosti" [Regulation of Accounting Policy of Financial Reporting]. Bukhhalterskyi oblik i audyt, no. 5 (2009): 24-34.

[Legal Act of Ukraine] (1999). https://zakon.rada.gov.ua/ laws/show/996-14 
Model of hotel accounting policy

\begin{tabular}{|l|l|}
\hline \multicolumn{1}{|c|}{ Features of hotel services } & \multicolumn{1}{c|}{ Elements of accounting policy } \\
\hline 1. Standardization and classification of hotel activities & $\begin{array}{l}\text { Application of a flexible remuneration system, based on the work } \\
\text { cycle of the hotel }\end{array}$ \\
\hline 2. Territorial location of the hotel & Technological specifics of the hotel work \\
\hline 3. Organization of customer service & $\begin{array}{l}\text { Incomplete hotel occupancy cannot be compensated for } \\
\text { in the future }\end{array}$ \\
\hline 4. Identity of production and consumption of the service & $\begin{array}{l}\text { Quality control (absence of work in progress and residues } \\
\text { of finished products) }\end{array}$ \\
\hline 5. Seasonal nature of consumption & The hotel room occupancy is uneven \\
\hline 6. Flexible work schedule & Flexible working schedule of the hotel servants \\
\hline 7. There is no need to store the hotel product & Marketing policy (application of flexible pricing policy) \\
\hline 8 Form of consumption of services & $\begin{array}{l}\text { Organization of expense tracking during the implementation } \\
\text { of the system of self-service for hotel visitors }\end{array}$ \\
\hline 9. Long-term hotel stay & $\begin{array}{l}\text { At the end of using the hotel service, the total cost of providing } \\
\text { services is calculated, with making adjustments to the previous bill }\end{array}$ \\
\hline 10. Close cooperation with hotel customers & $\begin{array}{l}\text { Organization of the control and rationalization of the production } \\
\text { process }\end{array}$ \\
\hline
\end{tabular}

\begin{tabular}{|c|c|c|}
\hline & 23 Production & \multirow[b]{2}{*}{$\downarrow$} \\
\hline$\downarrow$ & $\downarrow$ & \\
\hline 23.1 Main activities & 23.2 Related services & 23.3 Extras \\
\hline$\downarrow$ & $\downarrow$ & $\downarrow$ \\
\hline $\begin{array}{l}\text { 23.11 Room reservation } \\
\text { and registration services } \\
\text { 23.12 Cleaning } \\
\text { 23.13 Laundry services } \\
\text { 23.14 Maintenance of the } \\
\text { production cycle } \\
\text { 23.15 Other services }\end{array}$ & $\begin{array}{l}\text { 23.21 Luggage storage } \\
\text { 23.22 Communications services } \\
\text { 23.23 Bar services } \\
\text { 23.24 Café services } \\
\text { 23.25 Restaurant services } \\
\text { 23.26 Medical services } \\
\text { 23.27 Housekeeping } \\
\text { 23.28 Parking } \\
\text { 23.29 Security } \\
\text { 23.30 Other services }\end{array}$ & $\begin{array}{l}\text { 23.31 Sauna services } \\
\text { 23.32 Hairdressing services } \\
\text { 23.33 Billiards } \\
\text { 23.34 Computer services } \\
\text { 23.35 24/7 Transport service } \\
\text { 23.36 International } \\
\text { communication services } \\
\text { 23.37 Business center services } \\
\text { 23.38 Excursion services } \\
\text { 23.39 Sports and recreation } \\
\text { center } \\
\text { 23.310 Concession stands } \\
\text { 23.311 Dry cleaning } \\
\text { 23.312 Currency exchange } \\
\text { 23.313 Other services }\end{array}$ \\
\hline
\end{tabular}

Fig. 4. Recommended chart of accounts (sub-ledger accounts reflecting production costs) of the hotel

[Legal Act of Ukraine] (2005). http://195.78.68.18/minfin/control/uk/publish/article?art_id=58984\&cat_ id $=34931$

Lebedzevych, Ya. V. "Vplyv oblikovoi polityky pidpryiemstva na dokhody i rezultaty diialnosti" [The Impact of Accounting Policies of the Enterprise on Income and Results of Operations]. Visnyk ZhITI, no. 15 (2001): 155-162.

"MSBO (IAS) 8. Oblikovi polityky, zminy v oblikovykh otsinkakh ta pomylky" [IAS 8. Accounting Policies, Changes in Accounting Estimates and Errors]. https:// zakon.rada.gov.ua/laws/show/929_020
Pryanichnikova, I. “Pervyy shag k MSFO: novaya uchetnaya politika" [The First Step to IFRS: New Accounting Policies]. Balans, no. 63 (2007): 31-34.

Pushkar, M. S. Oblikova polityka izvitnist [Accounting Policy and Reporting]. Ternopil: Kart-blansh, 2004.

Shchyrba, M. "Problemy dokumentalnoho oformlennia oblikovoi polityky pidpryiemstva ta shliakhy yikh vyrishennia" [Problems of Documenting the Accounting Policy of the Enterprise and Ways to Solve Them]. Ekonomichnyi analiz, no. 5 (2010): 380-384.

Yancheva, L. M., Herasymova, N. S., and Levina, M. V. Obliki audyt hotelnykh posluh [Accounting and Audit of Hotel Services]. Kharkiv: KhDUKhT, 2013. 